\title{
The identity of the violet flowered water lily (Nymphaeaceae) and its hybrid origin in the wetland ecosystems of Sri Lanka
}

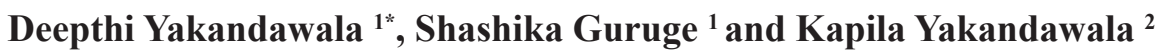 \\ ${ }^{I}$ Department of Botany, Faculty of Science, University of Peradeniya, Peradeniya. \\ ${ }^{2}$ Department of Horticulture and Landscape Gardening, Faculty of Agriculture and Plantation Management, Wayamba University of Sri Lanka, \\ Makandura, Gonawila.
}

\begin{abstract}
The Sri Lankan violet water lily (Dam-manel) that is widely spread in natural water bodies of the country has been erroneously identified as Nymphaea nouchali (Nil-manel) in literature. Further the image of this flower, which has been erroneously used to depict the national flower of the country for nearly three decades, has not been taxonomically described and therefore does not have a botanical identity. Many scientific studies have been conducted on different aspects of the violet coloured water lily under either the erroneous identification or without a proper scientific name. The present study was conducted with the aim of clarifying its confused identity with $N$. nouchali, and also elucidating the parentage of the hybrid origin of Sri Lankan violet water lily using morphological and matK and psbA-trnH molecular sequence data. The morphometric analyses and the results of the BLAST search confirmed the identity of the native $N$. nouchali, and recognised the Sri Lankan violet water lily as a hybrid of $N$. micrantha and $N$. caerulea. Therefore, the plant is named and described as a new hybrid, Nymphaea $\times$ erangae Yakandawala, Guruge \& Yakandawala. A taxonomic description is also provided for the newly described hybrid.
\end{abstract}

Keywords: Hybrid Nymphaea $\times$ erangae, Nymphaea nouchali, violet water lily.

\section{INTRODUCTION}

The water lilies or 'Nymphaeas' are one of the most conspicuous and eye catching plant groups inhabiting the waterbodies of the lowlands in Sri Lanka together with Nelumbo (E: Lotus, S: Nelum). They belong to the genus Nymphaea of the family Nymphaeaceae and three Nymphaea species have been recorded as occurring in the island; N. nouchali Burm. f. (syn: N. stellata Willd.) (S: Nil-manel or Manel), N. pubescens Willd. (S: Olu) and N. rubra Roxb. ex Andrews (S: Rathu-olu or Rathberaliya) (Dassanayake, 1996; Guruge et al., 2014). In addition to the native water lilies, a few ornamental exotic Nymphaea species have also been introduced in the past for aquatic landscapes. Among these, a large violet flowered water lily, 'Dam-manel' (S) has got extensively established in natural water bodies. This plant has been erroneously identified as $N$. nouchali, the native water lily, in literature both locally and internationally (Yakandawala \& Yakandawala, 2011 and reference therein). There are no records of the era when this violet water lily was introduced to the country, but according to the prevailing evidence, its initial introduction would have been well over 50 years. Interestingly, it is an image of this flower that was erroneously used to depict the national flower of Sri Lanka, Nymphaea nouchali in the official publication (CEA, 1992), and thereby the mistake was widely continued in other documentations for three decades until the error was rectified in June 2015. This provides evidence for its fame and abundance in natural waterbodies even at the time of declaration of the national flower in 1986.

The large attractive flowers of the violet water lily are popular in aquatic landscapes and aquatic cut flower industry, especially as they are offered at Buddhist

*Corresponding author (deepthiy@pdn.ac.lk; (iD https://orcid.org/0000-0003-2441-5510) 
temples and shrines throughout the country. According to Subashini et al. (2014), the violet water lily has a high demand as a cut flower in Sri Lanka and is the second aquatic cut flower species in demand of Buddhist religious places after white lotus. Initially the plant would have been restricted to controlled landscapes, but now it has escaped from the controlled environments and is naturalised and occurrs in all parts of the island except at higher elevations (Yakandawala \& Yakandawala, 2011). Further, due to its ornamental value, ornamental plant growers would have been involved in importing and distributing this exotic plant in the past. Therefore, it is probable that many successive introductions occurred where they got naturalised. Compared to the native $N$. nouchali, the exotic violet Nymphaea has a rapid mode of vegetative reproduction, where it is capable of producing proliferous leaves (Yakandawala $\&$ Yakandawala, 2011). The mature leaves of this violet Nymphaea are capable of developing a young plantlet at the leaf base where the petiole meets the lamina. This has contributed to its rapid spread in local water bodies while the flawed identification as the national flower, together with the demand as a cut flower has contributed to its popularity throughout the country.

The validity of a scientific study where organisms are involved, solely depends on the identity of the organism concerned. Further, the correct scientific name would also provide the key for a wealth of information. Although the violet water lily has been present in the island for over a half century, the plant was not taxonomically described during the revision of the Nymphaeaceae in the 'Revised Handbook to the Flora of Ceylon' (Dassanayake, 1996), and therefore currently this exotic violet water lily does not have a botanical identity. Many scientific studies have been conducted on different aspects of the violet water lily under either the wrong identification or without a proper scientific name due to the unavailability of a taxonomic placement to the plant (Samarakoon \& Peiris, 2005; Tetali et al., 2008). According to morphological evidence the violet water lily is a hybrid taxa involving either N. capensis Thunb. or N. caerulea Savigny as one parent and N. micrantha Guill. \& Perr. as the other during its parentage history (Yakandawala \& Yakandawala, 2011).

Therefore, the present study was conducted with the objective of clarifying the identity of native $N$. nouchali and the violet water lily that is naturalised in the lowlands of Sri Lanka using morphological and matK and $p s b A$ $\operatorname{trn} H$ molecular sequence data. This is important not only taxonomically, but also for other areas of biology, since many studies have been conducted on this plant with reference to an erroneous identification or without referring to a scientific name.

\section{METHODOLOGY}

\section{Morphological studies}

\section{Sample collection}

As the identity of the violet water lily was linked with the native $N$. nouchali, both plants were included in the study. Field visits were made covering all three major climatic zones of the island, viz. Wet, Intermediate and Dry zones from $2006-2015$ (Figure 1). Hundred and thirty two individuals were collected from different populations, and each individual was denoted by a unique acronym to facilitate its reference. Morphological characters were studied in detail in the laboratory. Voucher specimens and live collections were maintained at the Department of Botany, University of Peradeniya, Sri Lanka and the Wayamba University of Sri Lanka during the study.

\section{Character coding}

Data were obtained from the individuals of both species randomly selected from each population and qualitative and quantitative characters were examined in the laboratory, either with the naked eye, or under a dissecting or a stereomicroscope (Leica, 10446322, 2X WD). The colour of the flower, leaf abaxial and adaxial surfaces and petiole was determined using the Royal Horticultural Society Colour Chart (RHS Colour Chart, 2001). Special attention was paid to the characters with distinct variations. Fruit and seed data were collected from the individuals of the same population. Fruits were never encountered from the violet water lily species. Therefore, ten individuals each representing four different populations were observed for seed set by bagging the flowers $3-4$ days after the initial blooming, just before they move under water. The list of characters together with the character states employed in the morphometric analyses is given in Table 1 .

\section{Data analysis}

Principal coordinate analysis $(\mathrm{PCoA})$ and hierarchical cluster analysis (CA) were carried out using the statistical software PAST (ver. 2.15) (Hammer et al., 2001). The cluster solution was selected from the best suitable algorithm, where Gower distance was used to calculate the similarity measures with the un-weighted pair-group method with arithmetic mean (UPGMA) option and the single linkage algorithm with the highest cophenetic correlation value. The ordination analysis was performed with the Gower distance (transformation exponent $\mathrm{C}=2$ ) to generate a distance matrix for using in 


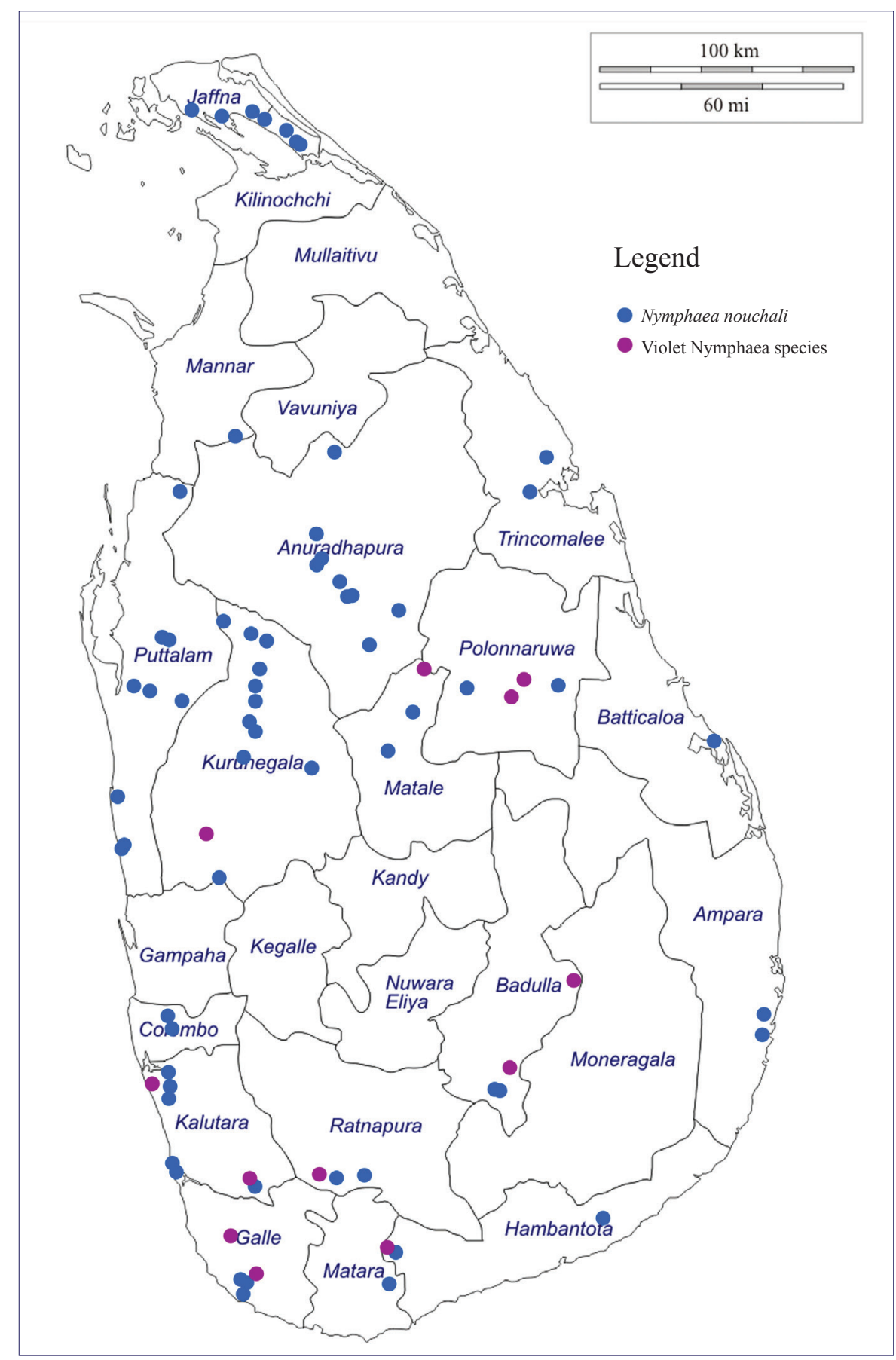

Figure 1: Map of Sri Lanka indicating the locations of sample collection

the PCoA. Following the results of these analyses, each major, consistently recovered cluster was identified.

\section{Molecular studies}

Genomic DNA was extracted from fresh young leaf samples, dried and stored with desiccated silica gel, using the Qiagen plant DNA extraction kit (Qiagen, Valencia, CA). The two chloroplast gene regions matK [(matK-390f 5'-CGATCTATTCATTCAATATTTC- 3', matK-1326r 5'-TCTAGCACACGAAAGTCGAAGT- 3') (Cuenoud et al., 2002)] and psbA-trnH [(psbA-F 5' -GTTATGCATGAACGTAATGCTC- 3' (Sang et al., 1997), trnH-R 5'- CGCGCATGGTGGATTCACAATCC-3' 
(Tate \& Simpson, 2003)] were amplified using the polymerase chain reaction (PCR) technique. All the amplifications used Promega GoTaq ${ }^{\circledR}$ Flexi DNA polymerase (Madison, WI, USA) according to manufacturer's recommendations. The PCR amplifications were carried out in $50 \mu \mathrm{L}$ reaction solutions that contained $1 \times$ PCR reaction buffer, $2.5 \mathrm{mM}$ $\mathrm{MgCl}_{2}, 0.2 \mathrm{mM}$ deoxynucleotide triphosphate (dNTPs), $0.2 \mu \mathrm{M}$ each forward and reverse primer, $1 \mathrm{U}$ of Taq DNA polymerase and $0.75-1.5 \mu \mathrm{L}$ unquantified DNA extract. The PCR programme was run on Eppendorf mastercycler thermal cycler (Hauppauge, NY, USA). The programme consisted of $3 \mathrm{~min}$ of initial denaturation at $94{ }^{\circ} \mathrm{C}, 35$ cycles of $30 \mathrm{~s}$ denaturation at $94{ }^{\circ} \mathrm{C}, 30 \mathrm{~s}$ annealing at $48{ }^{\circ} \mathrm{C}$ and $57^{\circ} \mathrm{C}$ for $m a t K$ and $p s b A$-trnH, respectively,
1 min primer extension at $72{ }^{\circ} \mathrm{C}$, followed by a final extension for $10 \mathrm{~min}$ at $72{ }^{\circ} \mathrm{C}$. The PCR products were run on $1 \%$ agarose gel stained with ethidium bromide and visualised on a UV illuminator. The molecular mass of the resulted bands was estimated with a $1 \mathrm{~kb}$ DNA ladder and the amplification of the primer was confirmed. The obtained PCR products were submitted for sequencing reactions using Applied Biosystems, 3500 genetic analyser (Department of Molecular Biology and Biotechnology, Faculty of Science, University of Peradeniya, Sri Lanka). matK amplified PCR products were sequenced for both forward and reverse primers using the same primer pairs as in the PCR amplification, while only one sequence was obtained for all the PCR products with amplified $p s b A$-trnH with forward primer.

Table 1: List of characters together with their character states used in the morphometric analyses

\begin{tabular}{|c|c|}
\hline Character & Character state \\
\hline Shape of the flower bud & Linear, oblanceolate \\
\hline Flower diameter & $\mathrm{cm}$ \\
\hline Diameter of the receptacle & $\mathrm{cm}$ \\
\hline Receptacle height & $\mathrm{cm}$ \\
\hline \multicolumn{2}{|l|}{ Flower colour } \\
\hline Petal apex & Pink, white, pale blue, violet \\
\hline Petal base & Pink, white, pale blue, yellowish \\
\hline \multicolumn{2}{|l|}{ Number of petals } \\
\hline Petal length (outer petals) & $\mathrm{cm}$ \\
\hline Petal width at the base (outer petals) & $\mathrm{cm}$ \\
\hline Petal width (maximum) (outer petals) & $\mathrm{cm}$ \\
\hline Petal shape & Linear-lanceolate, ovate-lanceolate, ob-lanceolate \\
\hline \multicolumn{2}{|l|}{ Number of veins per petals } \\
\hline Petal apex-shape and angle & Acute, obtuse \\
\hline \multicolumn{2}{|l|}{ Number of stigmatic segments } \\
\hline Diameter of the stigmatic disk & $\mathrm{cm}$ \\
\hline Length of central projection & $\mathrm{mm}$ \\
\hline Width of central projection at base & $\mathrm{mm}$ \\
\hline \multicolumn{2}{|l|}{ Number of sepals } \\
\hline Sepal length & $\mathrm{cm}$ \\
\hline Sepal width (maximum) & $\mathrm{cm}$ \\
\hline Sepal width at base & $\mathrm{cm}$ \\
\hline Sepal shape & Linear-lanceolate, ovate-lanceolate \\
\hline Sepal colour-inner surface - middle & Pink, white, pale blue, violet \\
\hline Sepal colour-inner surface - base & Pinkish white, white/pale blue, yellowish violet \\
\hline Sepal colour-outer surface - middle & Light green, green \\
\hline Sepal colour- outer surface - base & Light green, green \\
\hline Sepal apex - shape and angle & Acute, obtuse, curved \\
\hline Sepal striation & Low, high \\
\hline \multicolumn{2}{|l|}{ Number of stamens } \\
\hline Diameter of stamen whorl & $\mathrm{cm}$ \\
\hline Stamen length (outer most whorl) & $\mathrm{mm}$ \\
\hline
\end{tabular}

Continued - 
- continued from page 384

\begin{tabular}{ll}
\hline Character & Character state \\
\hline Leaf width & $\mathrm{cm}$ \\
Distance of leaf apex & $\mathrm{cm}$ \\
Appendage length (outer most whorl) & $\mathrm{mm}$ \\
Appendage width (outer most whorl) & $\mathrm{mm}$ \\
Anther length (outer most whorl) & $\mathrm{mm}$ \\
Anther width (outer most whorl) & $\mathrm{mm}$ \\
Filament length (outer most whorl) & $\mathrm{mm}$ \\
Filament width (outer most whorl) & mm \\
Pedicel diameter & $\mathrm{cm}$ \\
Pedicel colour & Green, brown, red \\
Pedicel shape in cross section & Round, slightly flat, oval \\
Pedicel - cross section & No. of lacunae \\
Petiole - cross section & No. of lacunae \\
Leaf shape & Round, ellipsoid \\
Leaf length & $\mathrm{cm}$ \\
Lamina colour (adaxial) & Dark green, light green, green \\
Lamina colour (abaxial) & Reddish-brown, violetto deep blue-violet, light \\
Leaf margin & green, brownish green \\
Leaf sinus and lobe tip & Dentate, wavy, smooth \\
Leaf adaxial surface streaks & V shape, overlapping \\
Leaf abaxial surface - dots & Present, absent \\
Leaf venation (abaxial) & Absent, present \\
Leaf apex & Strongly visible, visible, faintly visible \\
Petiole diameter & Division present, absent, not clear \\
Petiole shape in cross section & cm \\
Petiole colour & Round, elliptic \\
Leaf - cross section & Light green, reddish green \\
Vivipary & Curved shape, flattened shape \\
\hline & Present, absent \\
\hline
\end{tabular}

The raw sequences were screened and assembled and consensus for the resulted sequences of forward and reverse primers were compiled using Bioedit version 7.1.11 (Hall, 2011). Basic local alignment search tool or the BLAST (Altschul et al., 1997) was used to search the most similar sequence deposited in the GenBank, which would match the obtained sequence. The resulted sequences list was checked for the species identity of the respective species.

\section{RESULTS AND DISCUSSION}

\section{Morphological analyses}

The UPGMA dendrogram (cophenetic correlation coefficient $=0.9147)$ resolved two discrete clusters of operational taxonomic units (OTUs) (hereafter referred to as phenetic group 1 and 2), which is separated at an approximate distance of 0.45 units (Figure 2). The OTUs within the phenetic group 1 grouped together closely, as none of them exceeded a distance of more than 0.05 distance units within any given cluster (Figure 2). Further, the phenetic group 2 has shown internal clustering where two major sub clusters could be identified.

The first four (principal) eigenvalues recovered from the PCoA accounted for $98.6739 \%$ of the total variance (94.427, 2.8568, 0.86526, and $0.52484 \%$, respectively). A plot of the first and the second coordinates (which provided the greatest separation of OTUs) resulted in a separation similar to that obtained by the cluster analysis. Further, the PCoA also resolved two discrete clusters (Figure 3), with each corresponding exactly to one of the clusters indicated by the UPGMA dendrogram (Figure 3). 


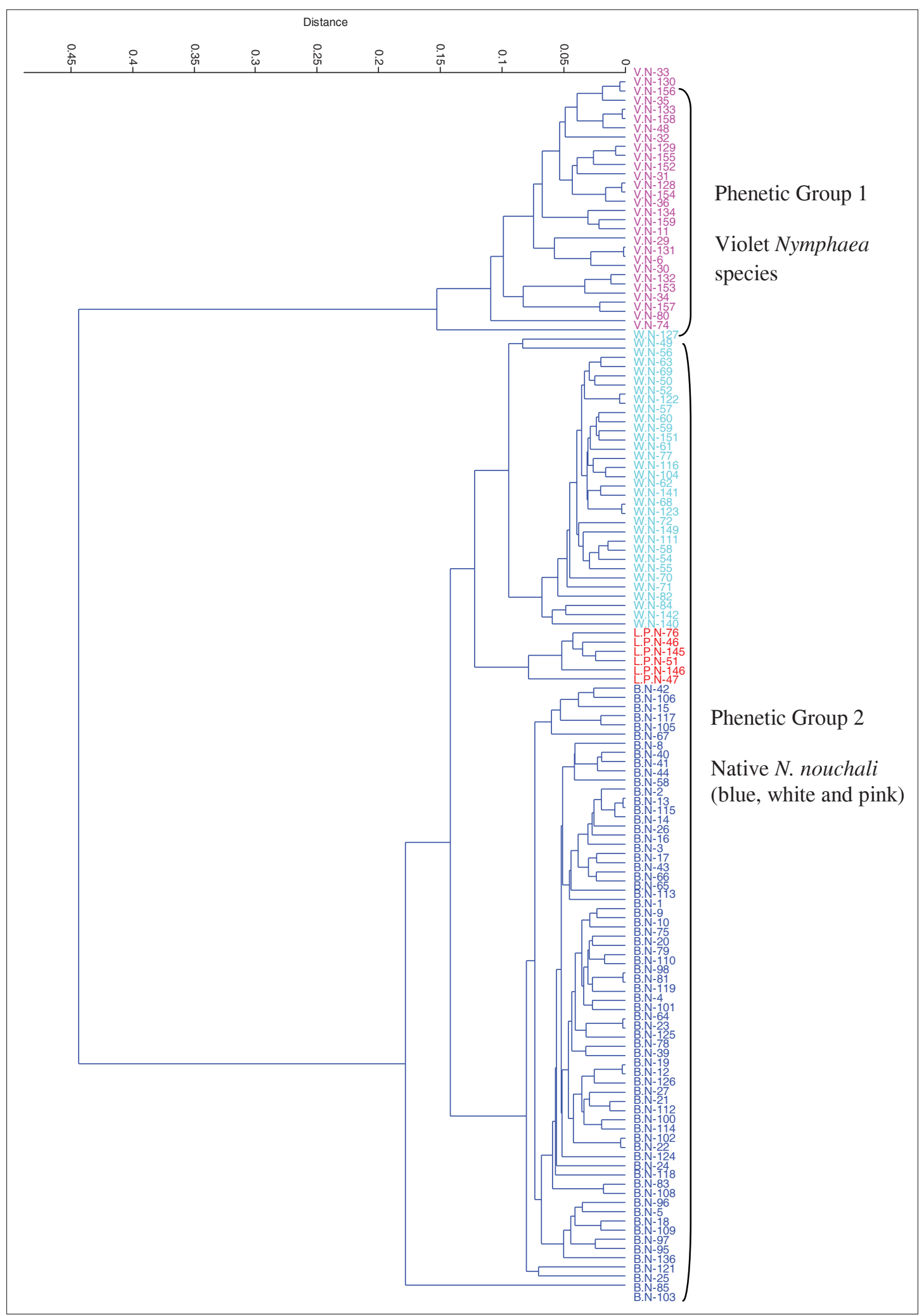

Figure 2: The dendrogram that resulted from the cluster analysis that was carried out to determine the identity of the violet flowered Nymphaea species using morphological characters. Phenetic group 1: violet Nymphaea species (OTUs = VN); phenetic group 2: native $N$. nouchali (OTUs $\mathrm{WN}=$ white flowers; $\mathrm{LPN}=$ pink flowers; $\mathrm{BN}=$ blue flowers) 


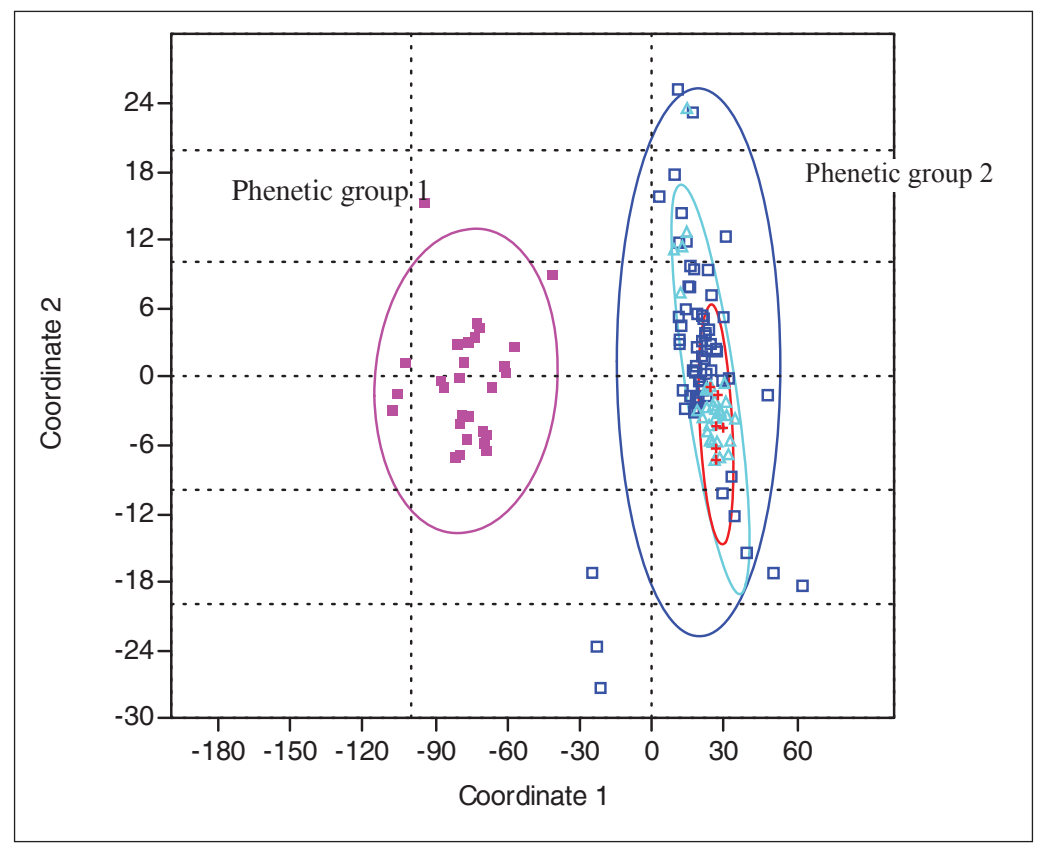

Figure 3: The scatter plot obtained from the PCoA that was carried out to determine the identity of the violet flowered Nymphaea species. Phenetic group 1: violet flowered Nymphaea species; phenetic group 2: native N. nouchali
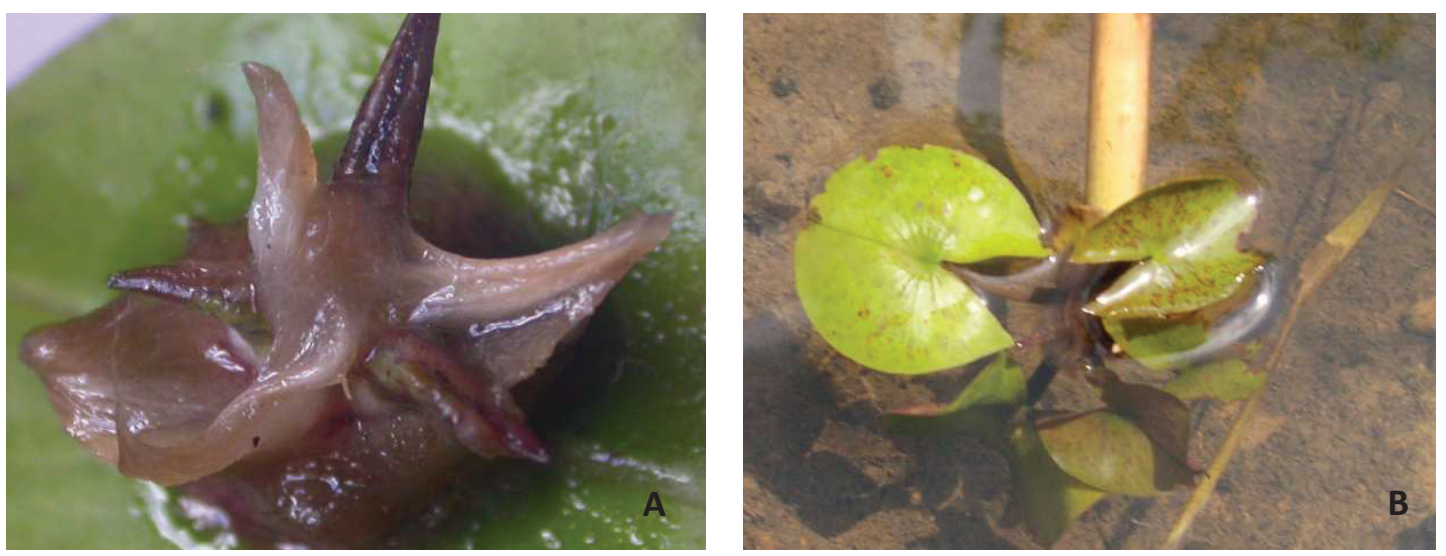

Figure 4: Different stages in the development of epiphyllous plantlets in Nymphaea with violet colour flowers. A: development of leaf primodia in the mucilaginous-nub at the leaf base where the petiole meets the leaf lamina; B: plantlets, still attached to the mother plant

The flowers of the violet water lily do not develop into mature fruits with seeds but degrade underwater; hence the attempts to collect fruit and seed characters were not successful. The plants reproduce viviparously. The term vivipary has been adopted by Cornad (1905) to refer to Nymphaea species that are capable of developing epiphyllous plantlets (in Greek epiphyllous mean 'upon a leaf').

\section{Development of epiphyllous plantlets or vivipary}

A spongy textured nub that is initiated at the point at which the leaf stalk and stem join, signals the initiation of vivipary. After about a week it becomes gelatinous, covered with mucilage, and soon shows a sign of developing leaves. As the leaf lamina of the mother plant becomes old, the plantlets develop 
further (Figure 4). Once detached from the deteriorated lamina, it is a miniature of the parent and is capable of floating away and establishing as an independent plant. Further blooming of these plants while still attached to the mother plant has also been observed.

\section{Molecular analyses}

After editing the raw sequences the resulted lengths were $896 \mathrm{bp}$ and $488 \mathrm{bp}$ for the matK and trnH-psbA gene regions, respectively. The comparison of the $m a t K$ and trnH-psbA gene regions between $N$. nouchali and the violet flowered Nymphaea showed $0.334 \%$ and $49.18 \%$ variations, respectively.

According to the results of the BLAST hit lists for the matK sequences, all native $N$. nouchali sequences showed a $100 \%$ sequence identity to $N$. nouchali (gene accession number FJ597752.1) (Dkhar et al., 2010). All the sequences obtained for the violet flowered Nymphaea showed a $100 \%$ match with $N$. micrantha with a query coverage of $100 \%$ (gene accession number DQ185541.1) (Loehne et al., 2007). Further, the three populations of the violet flowered Nymphaea matched with the gene accession number GQ468658.1, N. caerulea with a score of $100 \%, 99 \%$ and $98 \%$ (Dkhar et al., 2013) with a query coverage of $100 \%$ for each, respectively.

The $p s b A$-trn $H$ sequences of $N$. nouchali showed the highest similarity scores of $97 \%$ and $95 \%$ for $N$. cyanea (gene accession FJ527753.1) (Chaveerach et al., 2011) and $N$. nouchali, respectively, while the purple flowered Nymphaea showed $95 \%$ and $94 \%$ similarity scores for N. cyanea (gene accession FJ527753.1) (Chaveerach et al., 2011) and $N$. nouchali, respectively (gene accession FJ527754.1) (Chaveerach et al., 2011).

The results of the morphometric analysis clearly separate two phenetic groups within the studied OTUs. The comparison of morphological characters with described literature re-confirms the identity of phenetic group 2 (OTUs $\mathrm{WN}$ = white flowers, $\mathrm{LPN}=$ pink flowers and $\mathrm{BN}=$ blue flowers) as $N$. nouchali (Conard, 1905; Jacobs, 1994; Dassanayake, 1996; Fu \& Wiersema, 2001; Jacobs \& Hellquist, 2006; Jacobs \& Porter, 2007), whereas the specimens of the violet water lily - phenetic group 1 (OTUs of acronym $\mathrm{VN}$ ), unequivocally stands out. A fewer number of petals (average 14) and light yellow stamens (average 32); reddish brown or deep blue violet leaf abaxial surface and the absence of epiphyllous plantlets, are distinct morphological characters of native $N$. nouchali as opposed to the large number of petals (average 29) and yellow stamens (average 128); green leaf abaxial surface with purplish streaks and the ability to produce epiphyllous plantlets, of the violet water lily. The taxonomic position of the two sub-clusters within the phenetic group 2 corresponding to three flower colours, blue, white and pink (infraspecific level taxa of $N$. nouchali) has been discussed in details in a separate research article (Guruge et al., 2017).

Results of the BLAST search indicated $100 \%$ similarity for $m a t K$ and $95 \%$ similarity for $p s b A$-trnH gene sequences obtained for the three native $N$. nouchali that were sampled for the study.

Based on the morphological features, especially of the flower, it is similar to either $N$. capensis Thunb., $N$. cyanea Roxb. ex G. Don or N. caerulea Savigny. However the possibility is ruled out as the violet Nymphaea does not produce seeds as the other three species, but reproduces by developing epiphyllous plantlets or vivipary. The ability of the Sri Lankan violet Nymphaea to develop plantlets while still attached to the mother plant, provides the strongest clue on the identity of the possible other parent and its hybrid origin. Among the approximately 55 known species of Nymphaea in the world, the viviparous condition is rare and known only in three species; N. micrantha Guill. \& Perr., N. lasiophylla Mart. \& Zucc., and N. prolifera Wiersema (Monteverde, 2009). All three are tropical in distribution and $N$. micrantha is a day-bloomer while the other two exhibit nocturnal anthesis. Nymphaea micrantha belongs to Brachyceras while $N$. lasiophylla and N. prolifera belong to Hydrocallis (Slocum, 2005; Monteverde, 2009). The two species, N. lasiophylla and $N$. prolifera, exhibit vegetative propagation by means of abortive tuberiferous flowers (Monteverde, 2009). Proliferating leaves are recorded only in $N$. micrantha of West Africa (Wiersema, 1988; Slocum, 2005; Monteverde, 2009). The fact that this proliferating leaves appearing in the Nymphaea with violet flowers with a morphological resemblance to $N$. capensis, $N$. cyanea or $N$. caerulea provides a sturdy evidence of a hybridisation link to $N$. micrantha. Developing epiphyllous plantlets is a popular feature that has been incorporated during breeding of Nymphaea by horticulturists as it provides an easy means of propagation. Over thirty popular tropical day-blooming viviparous hybrids have been developed with $N$. micrantha as a parent and are popular in aquatic landscaping (Knotts, 2003). The parentage of many water lily hybrids and cultivars were kept hidden as trade secrets in the past, as new cultivars became profitable financially (Conard 1905; Les et al., 2004). 
According to the results, the matK gene sequences of the three populations of violet Nymphaea species indicated a $100 \%, 99 \%$ and $98 \%$ similarity respectively with $N$. caerulea [under certain circumscription it is considered a synonym of Nymphaea nouchali var. caerulea (Savigny) Verdc.] while they all matched $100 \%$ with $N$. micrantha. There were no sequences deposited for $N$. capensis for matK, and $p s b A$-trn $H$ gene region for $N$. caerulea and $N$. micrantha, for comparison.

According to the present study, the tentatively identified parents; $N$. caerulea and $N$. micrantha, based on morphological characters of the violet water lily has been supported by the molecular studies, where $N$. micrantha has provided strong supportive evidence to conclude the hybrid origin. The other speculated parent was either $N$. capensis, $N$. cyanea or $N$. caerulea (Yakandawala \& Yakandawala, 2011). The molecular evidence supports this identification where $N$. caerulea has high similarity scores (100\%, $99 \%$ and $98 \%)$ with the $m a t K$ gene region for the three populations. Therefore, the results confirmed the hybrid origin of the violet flowered Nymphaea, and propose the parentage as $N$. micrantha and $N$. caerulea.

As stated before this exotic hybrid violet water lily that was introduced for ornamental purposes has escaped from the controlled environments a long time ago and is now naturalised in the lowlands of the country. According to research, many of the species that turn out to be successful in a new environment only do so, either

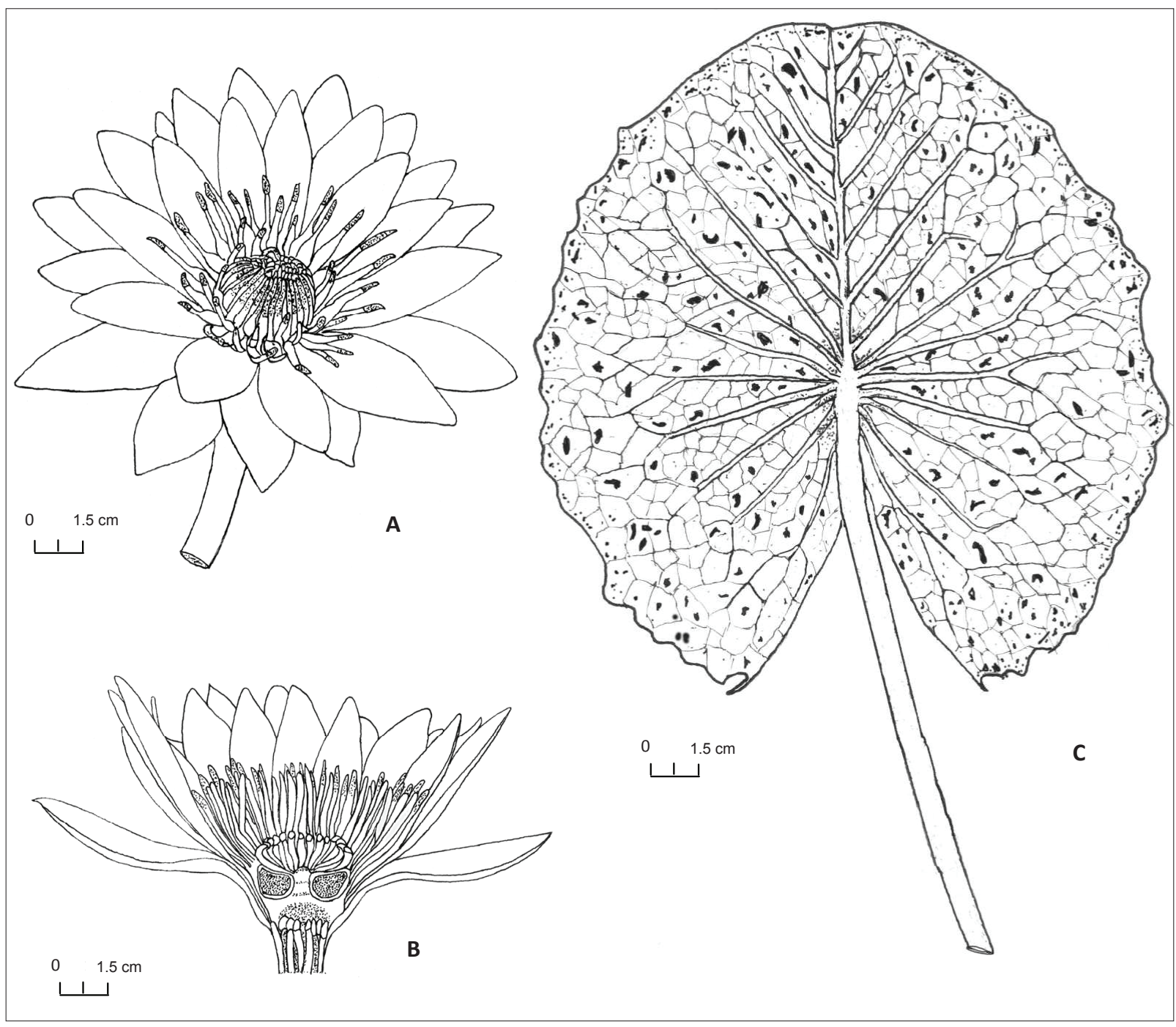

Figure 5: Nymphaea $\times$ erangae Yakandawala, Guruge \& Yakandawala. (A) flower; (B) half flower and (C) leaf abaxial surface 
following an unusually long lag time after the initial arrival, and/or after multiple introductions (Ellstrand \& Schierenbeck, 2006; Tiebre et al., 2007). The violet Nymphaea may have had multiple introductions and it is also possible that these introductions were not all the same hybrid but could have introgressed into a new hybrid. Such hybrids can be very successful invaders (Ellstrand \& Schierenbeck, 2006). Natural hybridisation often occurs whenever two or more species of Nymphaea occur together in the same waterbody. At present this plant has silently invaded the lowlands of the country (Yakandawala \& Yakandawala, 2011).
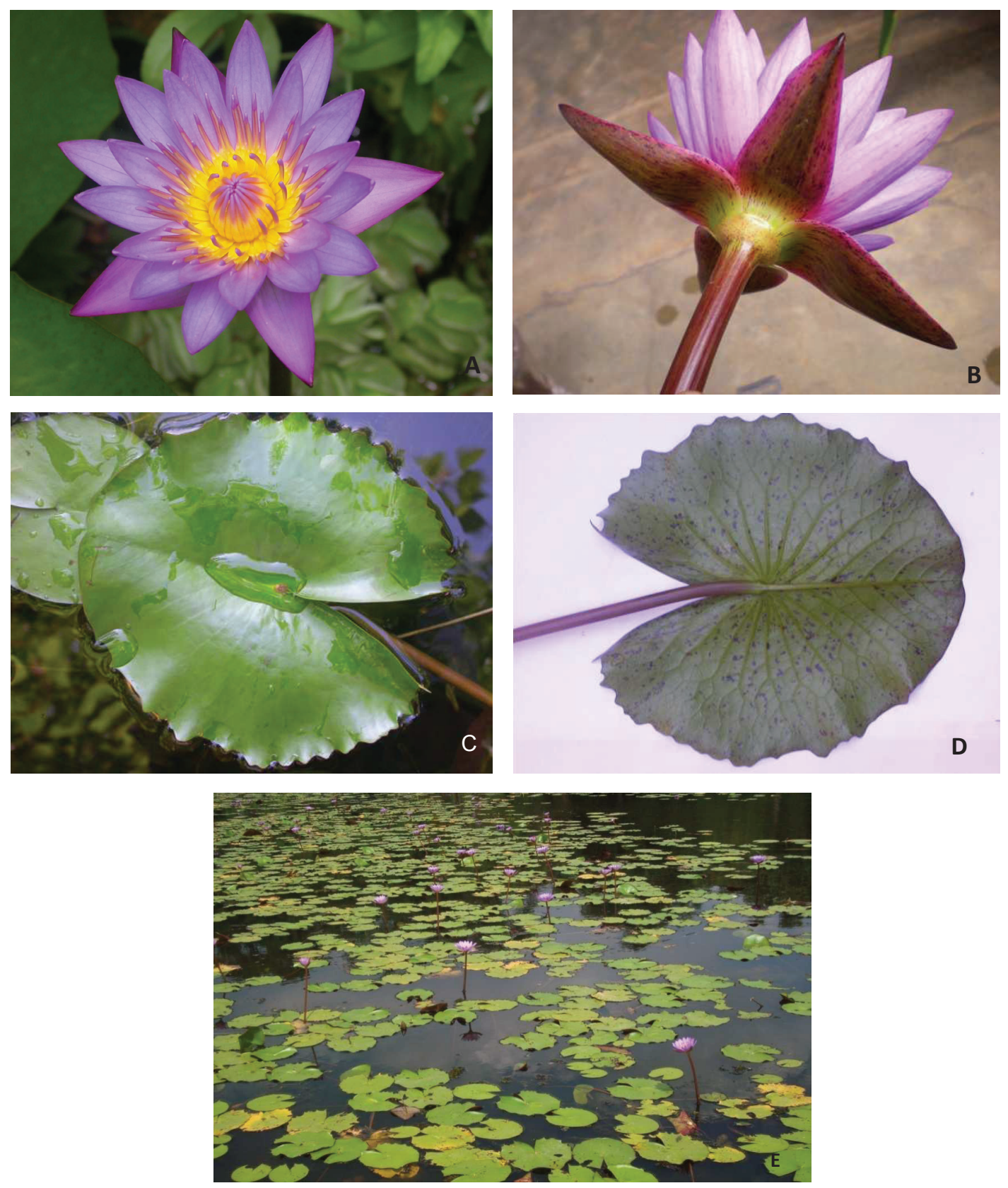

Figure 6: Nymphaea $\times$ erangae Yakandawala, Guruge \& Yakandawala. (A) flower; (B) sepals; (C) leaf adaxial surface; (D) leaf abaxial surface and (E) a natural population 
Reference to taxa with correct identification is very important in scientific studies, and the Sri Lankan violet water lily (Dam manel) has been occurring in the country over decades under either the wrong identity or without a proper identification. Therefore, the Sri Lankan naturalised violet water lily, which is widespread in major climatic zones of the country without identified parents growing in the surrounding, is described in the present study as a new hybrid taxon.

Nymphaea $\times$ erangae Yakandawala, Guruge \& Yakandawala, Hybr. Nov. (Figures 4, 5 and 6)

Type: Holotype: Sri Lanka, Kurunegala District, Kuliyapitiya. Yakandawala, Guruge \& Yakandawala 11, 21/06/2012 (PDA). Isotype: PDA.

Description: Rhizomes $5-15 \times 3.2-5 \mathrm{~cm}$. Leaves large or medium-sized, usually floating, stipulate, viviparous. Petioles $0.4-0.8 \mathrm{~cm}$ in diameter, terete, glabrous, brownish red. Lamina $13-30 \times 12-29 \mathrm{~cm}$, floating on the surface, coriaceous, smooth, glossy bright dark green above, green with purplish spots beneath, with prominent green veins, somewhat peltate, rotund, orbicular or suborbicular, incised-cordate at base. Sinus V-shaped at the base but sometimes lobes overlapping. Pedicel erect, stout, smooth, $0.8-2 \mathrm{~cm}$ in diameter, terete, reddish brown. Bud broadly conical. Sepals $3.5-6.5 \times 1.5-$ $2.5 \mathrm{~cm}$, lanceolate but broader towards base, acute and rounded towards apex, glabrous, coriaceous, outer purple towards margin, dark purple-green at the center and with purple narrow streaks all over, inner surface purple, greenish towards the base and smooth within. Petals 21 - 30, outer few petals somewhat similar to sepals; the outer petals $3-6 \times 1-2.2 \mathrm{~cm}$, inner smaller, lanceolate or narrowly elliptic, acute or subobtuse at apex, violet. Stamens $100-160$, the outer longer. Filaments flat, bright yellow, $0.8-1 \mathrm{~cm}$ long, $2-4 \mathrm{~mm}$ broad, the inner 0.5 $-0.8 \mathrm{~mm}$ long, c. $2 \mathrm{~mm}$ broad. Anthers $1-1.5 \mathrm{~cm}$ long, c. $2-3 \mathrm{~mm}$ broad, bright yellow, with a violet tongueshaped appendage, this in the outer stamens $5-8 \mathrm{~mm}$ long, in the innermost c. $1 \mathrm{~mm}$ long. Ovary $1.5-2 \mathrm{~cm}$ broad, yellow. Carpels $18-28$. Ovules embedded in mucilage. Stigmas bright yellow, rays acute, appendages curved upwards at the ends. The fading flower retracting under water and decaying without developing seeds.

Vernacular names: Violet water lily, 'Dam manel' Phenology: Flowers throughout the year

Habitat: Occurs naturally in large to small water bodies and in ditches. Often grown as an ornamental aquatic.

Distribution: Distributed in the Wet, Intermediate and Dry zone of the country.
Derivation: The hybrid name is in reference to our only son, Eranga Yakandawala, who has accompanied us on fieldwork since his childhood.

\section{CONCLUSION}

The Sri Lankan violet water lily that occurs widespread in natural water bodies and identified as $N$. nouchali in literature, which was depicted as the national flower of the country for nearly three decades is not $N$. nouchali. It is a hybrid between $N$. micrantha and $N$. caerulea. Therefore, the plant is named and described as a new hybrid, Nymphaea $\times$ erangae Yakandawala, Guruge \& Yakandawala.

\section{Acknowledgement}

The authors acknowledge Dr John H. Wiersema, Beltsville, Maryland, USA, a member of the Editorial Committee, International Code of Nomenclature for Algae, Fungi, and Plants, for invaluable comments and guidance provided on the nomenclatural issues; Prof. M.D. Dassanayake and Prof. N.K.B. Adikaram for constructive comments, and Mr I. Peabotuwage and Ms M. Ariyaratne for field assistance. Financial assistance provided by the National Science Foundation (grant number RG/2011/NRB/03) is gratefully acknowledged.

\section{REFERENCES}

1. Altschul S.F., Madden T.L., Schäffer A.A., Zhang J., Zhang Z., Miller W. \& Lipman D.J. (1997). Gapped BLAST and PSI-BLAST: a new generation of protein database search programs. Nucleic Acids Research 25(17): 3389 - 3402. DOI: https://doi.org/10.1093/nar/25.17.3389

2. Central Environmental Authority (CEA) (1992). Na and Manel. The National Tree and the National Flower of Sri Lanka (ed. V. Dharmasena), pp. 1 - 20. The Central Environmental Authority, Colombo, Sri Lanka.

3. Chaveerach A., Tanee T. \& Sudmoon R. (2011). Molecular identification and barcodes for the genus Nymphaea. Acta Biologica Hungarica 62(03): 328 - 340.

DOI: https://doi.org/10.1556/ABiol.62.2011.3.11

4. Conard H.S. (1905). The Waterlilies: a Monograph of the Genus Nymphaea, pp. 279. Carnegie Institute of Washington, USA.

DOI: https://doi.org/10.5962/bhl.title.51290

5. Cuenoud P., Savolainen V., Chatrou L.W., Powell M., Grayer R.J. \& Chase M.W. (2002). Molecular phylogenetics of Caryophyllales based on nuclear 18S rDNA and plastid $r b c \mathrm{~L}$, atp $\mathrm{B}$, and matK DNA sequences. American Journal of Botany 89(01): $132-144$.

DOI: https://doi.org/10.3732/ajb.89.1.132

6. Dassanayake M.D. (1996). Nymphaeaceae. A Revised 
Handbook to the Flora of Ceylon, volume 10 (eds. M.D. Dassanayake \& W.D. Clayton), pp. 289 - 292. Oxford and IBH Publishing Co. Pvt., Ltd., New Delhi, India.

7. Dkhar J., Kumaria S., Rao S.R. \& Tandon P. (2010). Molecular phylogenetics and taxonomic reassessment of four Indian representatives of the genus Nymphaea. Aquatic Botany 93(02): 135 - 139.

DOI: https://doi.org/10.1016/j.aquabot.2010.03.010

8. Dkhar J., Kumaria S., Rao S.R. \& Tandon P. (2013). New insights into character evolution, hybridization and diversity of Indian Nymphaea (Nymphaeaceae): evidence from molecular and morphological data. Systematics and Biodiversity 11(1): $77-86$.

DOI: https://doi.org/10.1080/14772000.2013.773949

9. Ellstrand N.C. \& Schierenbeck K.A. (2006). Hybridization as a stimulus for the evolution of invasiveness in plants. Euphytica 148: 35 - 46 .

DOI: https://doi.org/10.1007/s10681-006-5939-3

10. Fu D.Z. \& Wiersema J.H. (2001). Nymphaeaceae. Flora of China, volume 6 (eds. Z.Y. Wu \& P. Raven), pp. $115-$ 118. Missouri Botanical Garden Press, St Louis, USA and Science Press, Beijing, China.

11. Guruge S., Yakandawala D. \& Yakandawala K. (2014). Nymphaea rubra Roxb. ex Andrews in Sri Lankan fresh waters. Proceedings of the International Forestry and Environment Symposium, Sri Lanka. Department of Forestry and Environmental Science, University of Sri Jayewardenepura, Sri Lanka, p. 29.

12. Guruge S., Yakandawala D. \& Yakandawala K. (2017). A taxonomic synopsis of Nymphaea nouchali Burm. f. and infraspecific taxa. Journal of the National Science Foundation of Sri Lanka 45(3): 307 - 318.

DOI: https://doi.org/10.4038/jnsfsr.v45i3.8194

13. Hall T. (2011). BioEdit: An important software for molecular biology. GERF Bulletin of Biosciences 2(1): $60-61$.

14. Hammer Ø., Harper D.A.T. \& Ryan P.D. (2001). PAST: Paleontological statistics software package for education and data analysis. Palaeontologia Electronica 4(01): 1 - 9.

15. Jacobs S.W.L. (1994). Further notes on Nymphaea (nymphaeaceae) in Australia. Telopea 5(4): 703 - 706. DOI: https://doi.org/10.7751/telopea19934996

16. Jacobs S.W. \& Hellquist C.B. (2006). Three new species of Nymphaea (Nymphaeaceae) in Australia. Telopea 11: $155-160$.

DOI: https://doi.org/10.7751/telopea20065719

17. Jacobs S.W.L. \& Porter C.L. (2007). Nymphaeaceae. Flora of Australia (ed. A.J.G. Wilson), volume 2: Winteraceae to Platanaceae, pp. 259 - 275. ABRS, Canberra/CSIRO Publishing, Melbourne, Australia.

18. Knotts K. (2003). Viviparous Waterlilies. Available at https://www.victoria-adventure.org/waterlilies_images/ vivips/page1.html, Accessed 25 November 2010.

19. Les D.H., Moody M.L., Doran A.S. \& Phillips W.E. (2004). A genetically confirmed intersubgeneric hybrid in
Nymphaea L. (Nymphaeaceae Salisb.). HortScience 39(2): $219-222$.

20. Loehne C., Borsch T. \& Wiersema J.H. (2007). Phylogenetic analysis of nymphaeales using fast-evolving and noncoding chloroplast markers. Botanical Journal of the Linnean Society 154(2): $141-163$.

DOI: https://doi.org/10.1111/j.1095-8339.2007.00659.x

21. Monteverde J. (2009). The origins of viviparism in waterlilies. WGI Online 4(2). Available at http://www. watergardenersinternational.org/journal/4-2/jorge/page1_ en.html. Accessed 25 November 2010.

22. Royal Horticultural Society Colour Chart (2001). R.H.S. Enterprises, Ltd., The R.H.S. Garden, Wisley, Woking, Surrey, England.

23. Samarakoon U.C. \& Peiris S.E. (2005). Control of Circadian rhythm regulated nyctinastic movement in water lily (Nymphea stellata) flowers. Journal of Horticultural Science and Biotechnology 80(2): 167 - 170.

DOI: https://doi.org/10.1080/14620316.2005.11511911

24. Sang T., Crawford D. \& Stuessy T. (1997). Chloroplast DNA phylogeny, reticulate evolution, and biogeography of Paeonia (Paeoniaceae). American Journal of Botany 84(08): 1120 - 1120 .

DOI: https://doi.org/10.2307/2446155

25. Slocum P.D. (2005). Waterlilies and Lotuses: Species, Cultivars, and New Hybrids, pp. 1 - 208. Timber Press, Inc., USA.

26. Subashini J.K.W.N., Yakandawala K. \& Yakandawala D. (2014). Ornamental aquatic flower industry in Sri Lanka: demand, supply and barriers in the market from vendors' context. Proceedings of the $13^{\text {th }}$ Agricultural Research Symposium, Faculty of Agriculture and Plantation Management, Wayamba University of Sri Lanka, $7-8$ August, pp. $382-386$.

27. Tate J.A. \& Simpson B.B. (2003). Paraphyly of Tarasa (Malvaceae) and diverse origins of the polyploid species. Systematic Botany 28(04): 723 - 737.

28. Tetali P., Sutar S. \& Tetali S. (2008). Selective insectivory in Nymphaea nouchali Burm.f. Nature Precedings: hdl:1010/ npre.2008.1817.1. Available at http://precedings.nature. com/documents/1817/version/1/files/npre20081817-1.pdf. Accessed 18 November 2010.

29. Tiebre M.S., Bizoux Jean-P., Hardy O.J., Bailey J.P. \& Mahy G. (2007). Hybridization and morphogenetic variation in the invasive alien Fallopia (Polygonaceae) complex in Belgium. American Journal of Botany 94(11): $1900-1910$.

DOI: https://doi.org/10.3732/ajb.94.11.1900

30. Wiersema J.H. (1988). Reproductive biology of Nymphaea (Nymphaeaceae). Annals of the Missouri Botanical Garden 75: $795-804$.

DOI: https://doi.org/10.2307/2399367

31. Yakandawala D. \& Yakandawala K. (2011). Hybridization between native and invasive alien plants: an overlooked threat to the biodiversity of Sri Lanka. Ceylon Journal of Science (Biological Sciences) 40(01): 13 - 23. 